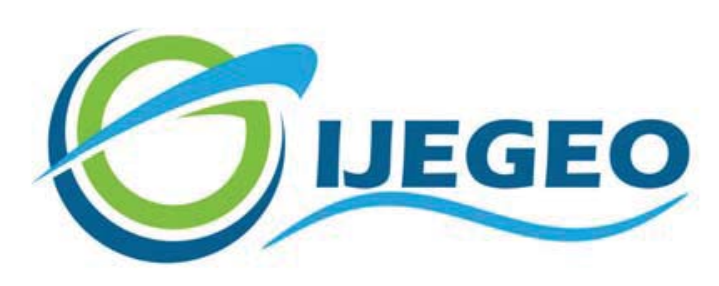

International Journal of Environment and Geoinformatics (IJEGEO) is an international, multidisciplinary, peer reviewed, open access journal.

\title{
Investigation of Potential Prevailing Wind Impact on Land Surface Temperature at Gas Flaring Sites in the Niger Delta, Nigeria
}

\section{Barnabas O. MORAKINYO, Samantha LAVENDER, Victor ABBOTT}

\author{
Chief in Editor \\ Prof. Dr. Cem Gazioğlu \\ Co-Editors Prof. Dr. Dursun Zafer Şeker, Prof. Dr. Şinasi Kaya, \\ Prof. Dr. Ayşegül Tanık and Assist. Prof. Dr. Volkan Demir
}

Editorial Committee (March 2022)

Assoc. Prof. Dr. Abdullah Aksu (TR), Assoc. Prof. Dr. Uğur Algancı (TR), Assoc. Prof. Dr. Aslı Aslan (US), Prof. Dr. Levent Bat (TR), Prof. Dr. Paul Bates (UK), İrşad Bayırhan (TR), Prof. Dr. Bülent

Bayram (TR), Prof. Dr. Luis M. Botana (ES), Prof. Dr. Nuray Çağlar (TR), Prof. Dr. Sukanta Dash (IN), Dr. Soofia T. Elias (UK), Prof. Dr. A. Evren Erginal (TR), Assoc. Prof. Dr. Cüneyt Erenoğlu (TR), Dr. Dieter Fritsch (DE), Prof. Dr. Ç; Prof. Dr. Manik Kalubarme (IN), Dr. Hakan Kaya (TR), Assist. Prof. Dr. Serkan Kükrer (TR), Assoc. Prof. Dr. Maged Marghany (MY); Prof. Dr. Micheal Meadows (ZA), Prof. Dr. Nebiye Musaoğlu (TR), Prof. Dr. Masafumi Nakagawa (JP), Prof. Dr. Hasan Özdemir (TR), Prof. Dr. Chyssy Potsiou (GR), Prof. Dr. Erol Sarı (TR), Prof. Dr. Maria Paradiso (IT), Prof. Dr. Petros Patias (GR), Prof. Dr. Elif Sertel (TR), Prof. Dr. Nüket Sivri (TR), Prof. Dr. Füsun Balık Şanlı (TR), Dr. Duygu Ülker (TR), Prof. Dr. Seyfettin Tsaş (TR), Assoc. Prof. Dr. Ömer Suat Taşkın (TR), Assist. Prof. Dr. Tuba Ünsal (TR), Assist. Prof. Dr. Sibel Zeki (TR) 


\title{
Investigation of Potential Prevailing Wind Impact on Land Surface Temperature at Gas Flaring Sites in the Niger Delta, Nigeria
}

Barnabas O. Morakinyo ${ }^{1,2,3,4}$ (D), Samantha Lavender ${ }^{2,3}$ (iD, Victor Abbott ${ }^{2}$ (iD

${ }^{1}$ Baze University, Faculty of Environmental Sciences, Department of Surveying \& Geoinformatics, Abuja, NIGERIA ${ }^{2}$ University of Plymouth, Faculty of Science \& Technology, School of Marine Science \& Engineering, Plymouth, UK ${ }^{3}$ Pixalytics Ltd, 1 Davy Rd, Tamar Science Park, Plymouth, UK

${ }^{4}$ ARGANS Ltd, 1 Davy Rd, Tamar Science Park, Plymouth, UK

How to cite: Morakinyo et al., (2022). Investigation of Potential Prevailing Wind Impact on Land Surface Temperature at Gas Flaring Sites in the Niger Delta, Nigeria, International Journal of Environment and Geoinformatics (IJEGEO, 9(1):179-190. DOI: 10.30897/ijegeo.968687

\begin{abstract}
This research examines the effects of South prevailing wind on Land Surface Temperature (LST) retrieved from Earth Observation (EO) Satellites at 11 gas flaring sites in Rivers State, Niger Delta region, Nigeria. 7 Landsat 5 Thematic Mapper (TM) and 18 Landsat 7 Enhanced Thematic Mapper Plus (ETM+) from 17/01/1986 to 08/03/2013 with < 5 \% cloud contamination were considered. All sites are located within a single Landsat scene (Path 188, Row 057). The atmospherically corrected reflectance was used for the classification of 4 land cover (LC) types at each site. The emissivity $(\varepsilon)$ for each site is estimated by using standard values for determined LC from Look Up Table (LUT). The surface-leaving radiance $\left(L_{\lambda}\right)$ is computed from the atmospherically corrected thermal band 6 (High gain) and the emissivity $(\varepsilon)$ values. The Planck equation was inverted using Landsat calibration constants to derive LST. Geospatial analysis of LST results using ArcGIS show 6 ranges of LST values for all sites. For both sensors LST retrieved for the flare stack sources are the highest values compared to other locations within the sites. Wind directions and wind speeds for Landsat data acquisitions dates and the South prevailing wind were applied to the LST for assessing their effects on it. The results show that for Eleme I and II, and Onne, the p-values results showed that no statistically significant relationships between $\delta \mathrm{LST}$ values in different directions ( $\delta \mathrm{LST}_{\mathrm{NE}}, \delta \mathrm{LST}_{\mathrm{NS}}$ and $\delta \mathrm{LST}_{\mathrm{NW}}$ ) existed. For Obigbo site, the wind direction (South) for data acquisition date combined with the South prevailing wind to generate a noticeable impact on the LST towards the North-East and the North-West directions. For Alua, Bonny, Chokocho, Rukpokwu, Umurolu and Sara sites, the p-value obtained is statistically significant for all the $3\left(\delta \mathrm{LST}_{\mathrm{NE}}, \delta \mathrm{LST}_{\mathrm{NS}}\right.$ and $\left.\delta \mathrm{LST}_{\mathrm{NW}}\right)$ relationships; therefore, producing a circle flare $\delta \mathrm{LST}$ footprint. For Umudioga site, only $\delta \mathrm{LST}_{\mathrm{N}}$ versus $\delta \mathrm{LST}$ w is statistically significant, causing a noticeable effect on the flare $\delta \mathrm{LST}$ in the North-West direction. Based on these results, it can be concluded that the volume and rate of burning gas, and the speed of the South wind at the time of satellite overpass are major factors that determine the influence of the South prevailing wind on the LST retrieved at the flaring sites in the Niger Delta.
\end{abstract}

Keywords: Investigation, prevailing, wind, land surface temperature, gas flaring, Niger Delta.

\section{Introduction}

Gas flaring (GF) is part of the upstream oil and gas industry processes as a means of disposing of unwanted natural gas or as a measure for pressure relief through high temperature oxidation at the tip of a stack (Caseiro et al., 2018). GF are a globally, regionally and locally significant source of atmospheric pollutants (Nwaogu and Onyeze, 2020; Caseiro, et al., 2019). They can be detected by satellite remote sensing technology (Morakinyo, et al., 2020b). Several negative impacts of GF on the immediate surrounding (Nwaogu and Onyeze, 2020; Akinola, 2018) among others include increase in surface temperature (Lu et al., 2020; Dung et al., 2008), noise (Nwoye et al., 2014; Ismail and Umukoro, 2012), light pollution (Morakinyo, 2015), air pollution (Sekyi, 2017; Edino et al., 2010), visual pollution (Aromolaran, 2012; Ajao and Anurigwo, 2002) and heat stress (Aromolaran, 2012; Julius, 2011).
Most of the satellite techniques currently applied for detecting gas flaring platforms and for assessing their spatio-temporal variations (Liu et al., 2018; Zhang et al., 2015; Anejionu et al., 2015; Elvidge et al., 2013; Anejionu et al., 2014; Casadio et al., 2012; Ülker et al. 2020) are based on measurements acquired by different sensors e.g., Operational Linescan System (OLS), Moderate Resolution Imaging Spectroradiometer (MODIS), Visible Infrared Imaging Radiometer Suite (VIIRS), Along-Track Scanning Radiometer (ATSR), Land Remote Sensing Satellite (Landsat) in different portions of the electromagnetic spectrum (visible (VIS), near-infrared (NIR), shortwave infrared (SWIR), middle infrared (MIR), thermal infrared (TIR) (Faruolo et al., 2018). The combustion of natural gas in the air at the flaring sites typically results in radiant temperatures usually within the range of (1450-2200) K (Elvidge et al., 2015; Zhang et al., 2015; Faruolo et al., 2014; Elvidge et al., 2013; Reed, 1986) with a mean of around 1750 K (Elvidge et al., 2015; Zhang et al., 2015; Faruolo et al., 2014). The climate assessments for the study 
environment highlight the atmospheric pattern of the study area. The assessments of climatic parameters such as wind directions and wind speeds among others are important baseline variables for any continuing project activity in any place. Wind is created when air moves from areas of high pressure toward areas of low pressure. Factors that affect wind direction (Table 3) and wind speed (Table 4) are seasonal temperature changes, centripetal acceleration, air pressure and Earth's rotation (Barber, 2021). The climate of the Niger Delta is affected by ocean and atmospheric interactions both within and outside its environment, in which the Inter-Tropical Convergence Zone (ITCZ) plays a controlling factor. The movement of the ITCZ is associated with the warm humid maritime tropical air mass with its South-Western winds and the hot and dry continental air mass with its dry North-Eastern winds (Antai, et al., 2020; Tokuşlu et al., 2020; Edokpa and Nwagbara, 2017). The prevailing wind direction is the South-Western winds (Antai, et al., 2020; Edokpa and Nwagbara, 2017). This implies that the wind blew from the South towards the North, North-East and North-West directions of the study environment (Antai, et al., 2020). Furthermore, average wind speeds in Nigeria range from about $2 \mathrm{~m} / \mathrm{s}$ to about $4 \mathrm{~m} / \mathrm{s}$ with highest average speeds of about $3.5 \mathrm{~m} / \mathrm{s}$ and $7.5 \mathrm{~m} / \mathrm{s}$ in the South and North areas, respectively (Oyewole and Aro, 2018; Fagbenle and Karayiannis, 1994).

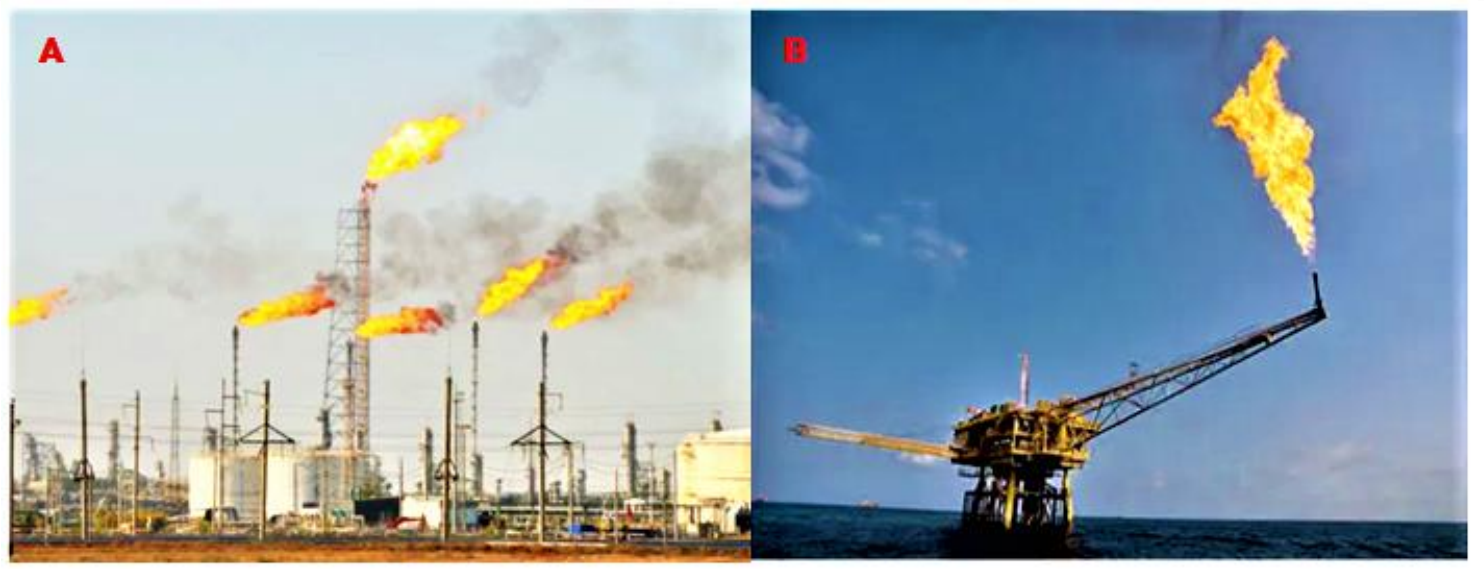

Fig. 1: Recent Nigeria's gas flaring scene in the Niger Delta; A) Onshore, Source: (Micheal, 2019); B) Offshore, Source: (Nwabughiogu, 2021).

The gaps before this study is that in the Niger Delta, limited research into investigating the effects of the prevailing wind on the Land Surface Temperature (LST) retrieved from Earth Observation Satellites (Landsat 5 TM and Landsat 7 ETM+) at the flaring sites has been published to date, and no research applied the methodology discussed in this paper. The basis for this research is the concept that combining remote sensing data with field survey data would result in significantly better analyses that give 2 dimensional spatio-temporal results. The 3 basic research questions for this study are: (1) What are different classes of LST retrieved from satellite data at the study sites in the Niger Delta? (2) Is there a detectable impact of wind direction on the spatial gradients in LST around the flares?

(3) What is the impact of the South prevailing wind on the LST retrieved at flaring sites in the Niger Delta? Based on these questions, the primary aim of this study is to examine the effects of the South prevailing wind on the LST retrieved from Landsat 5 TM and Landsat 7 ETM+ at the flaring sites in the Niger Delta. The specific objectives set for these research questions are: (1) Retrieval of LST from Landsat 5 TM and Landsat 7 ETM+ data at the flaring sites; (2) Parameterization of flare-related change in LST as $\delta$ LST; (3) Integration of wind directions and wind speeds data into the LST retrieved at the flaring sites; (4) Statistical analysis for the effects of the South prevailing wind on the LST.
In this paper, we present a spatial variation of LST at flare sites using ArcGIS for investigating the impacts of the South prevailing wind on the LST retrieved at flaring sites in the Niger Delta. Section 2 presents the study area and dataset used. Section 3 describes the developed methods; section 4 presents the results and finally, in section 5 we present summary and our conclusions.

\section{Study Area and Dataset Used Study Area}

All 11 flaring sites studied for this research are located in Rivers State of the Niger Delta region. The selection of the sites were based on the availability of Landsat data in the United State Geological Survey (USGS)/National Aeronautic and Space Administration (NASA) archive; function of the facility e.g. refineries, liquefied natural gas (LNG) plant, flow stations, terminals and oil wells; spatial dimensions of the facility; accessibility and location i.e. both coastal and inland facilities. The geographical coordinates of the sites limit lies approximately within Latitude $4^{\circ} 40{ }^{1}$ and $5^{\circ} 01^{1} \mathrm{~N}$ and Longitude $6{ }^{\circ} 50{ }^{1}$ and $7{ }^{\circ} 01^{1} \mathrm{E}$ (Morakinyo, 2015). The name, size of the facility, height of the flare stack and the geographical coordinate of the flare stack position within each site are presented in Table 1 . The size of the area examined around the flare stacks with Landsat satellite data is $12 \times 12 \mathrm{~km}$, in order to include sufficient data for detailed mapping of each site so that processes not related to flaring could also be resolved. 


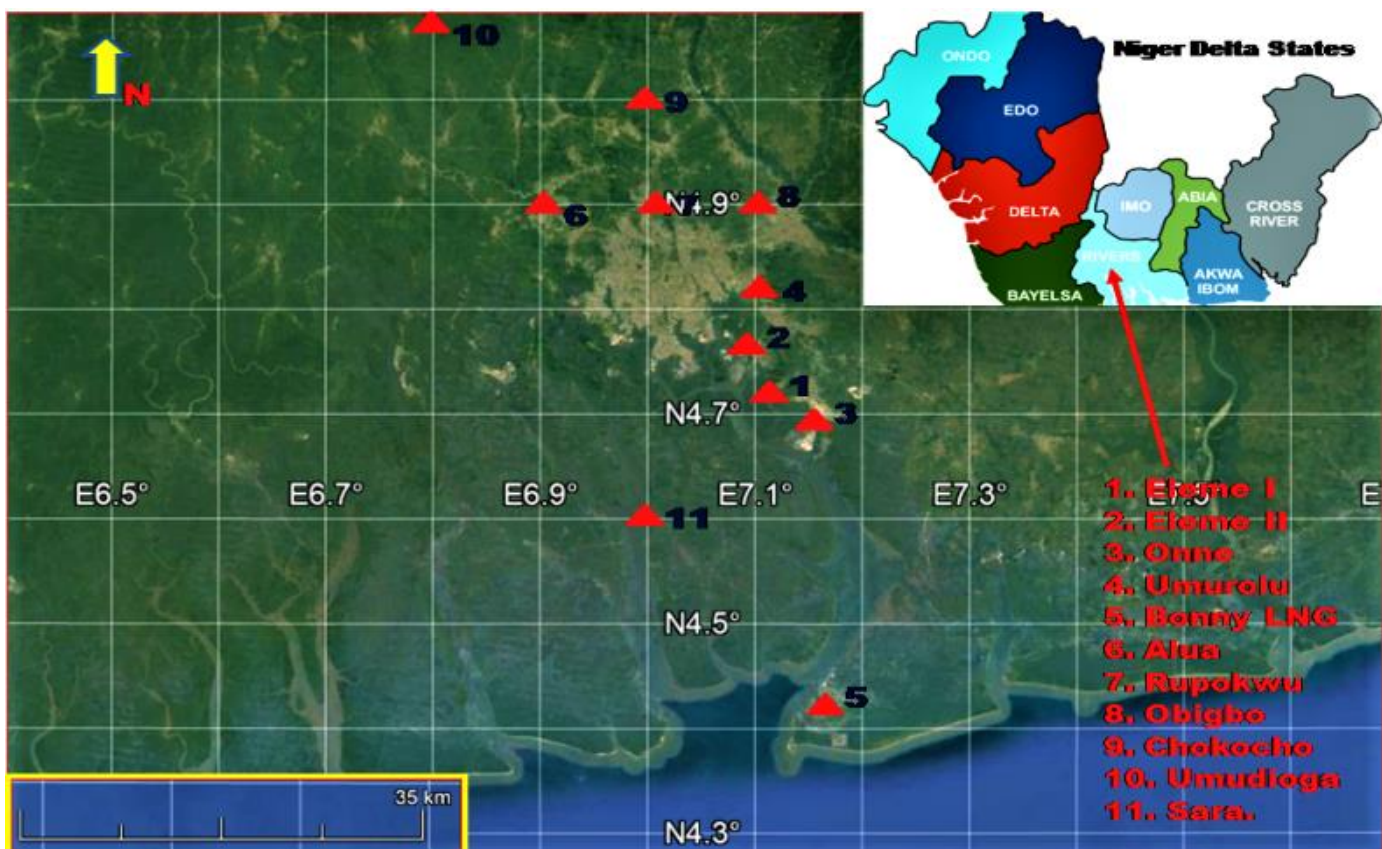

Fig. 2. Case study sites, Rivers States, Niger Delta Region of Nigeria; (Source: Google Earth, 2021; Nigerian Infopedia, 2021) Table 1: Name and size of the facility, their height of flare stack with their geographical coordinates.

\begin{tabular}{|c|c|c|c|c|c|c|}
\hline \multirow[t]{2}{*}{$\mathrm{S} / \mathrm{N}$} & \multirow[t]{2}{*}{ Name of the facility } & \multirow[t]{2}{*}{ Size of the facility } & \multicolumn{2}{|c|}{$\begin{array}{l}\text { Height of the flare } \\
\text { stack }(\mathrm{m})\end{array}$} & \multicolumn{2}{|c|}{$\begin{array}{l}\text { Geographical coordinates of the flare } \\
\text { stack position }\end{array}$} \\
\hline & & & & & Latitude $(\theta)$ & Longitude $(\lambda)$ \\
\hline 1. & $\begin{array}{l}\text { Eleme Refinery I Petroleum } \\
\text { Company }\end{array}$ & $1.6 \times 1.1 \mathrm{~km}$ & & & 4.729 & 7.119 \\
\hline 2. & $\begin{array}{l}\text { Eleme Refinery II Petroleum } \\
\text { Company }\end{array}$ & $2.2 \times 1.3 \mathrm{~km}$ & & & 4.762 & 7.111 \\
\hline 3. & Onne Flow Station & $175 \times 130 \mathrm{~m}$ & & & 4.712 & 7.141 \\
\hline 4. & Umurolu Flow Station & $4.2 \times 2.4 \mathrm{~km}$ & & & 4.830 & 7.109 \\
\hline 5. & $\begin{array}{l}\text { Bonny Liquefied Natural Gas } \\
\text { (LNG) Plant }\end{array}$ & $4.2 \times 2.8 \mathrm{~km}$ & & & 4.425 & 7.153 \\
\hline 6. & Alua Flow Station & $170 \times 90 \mathrm{~m}$ & & & 4.933 & 6.977 \\
\hline 7. & Rukpokwu Flow Station & $350 \times 350 \mathrm{~m}$ & & & 4.930 & 7.016 \\
\hline 8. & Obigbo Flow Station & $650 \times 650 \mathrm{~m}$ & & & 4.892 & 7.120 \\
\hline 9. & Chokocho Flow Station & $350 \times 120 \mathrm{~m}$ & & & 5.008 & 7.019 \\
\hline 10. & Umudioga Flow Station & $100 \times 100 \mathrm{~m}$ & & & 5.193 & 6.762 \\
\hline 11. & Sara Flow Station & $350 \times 250 \mathrm{~m}$ & & & 4.657 & 7.060 \\
\hline \multicolumn{7}{|c|}{ Table 2: List of Landsat 5 TM and Landsat 7 ETM+ used for the research } \\
\hline $\mathrm{S} / \mathrm{N}$ & Scene Identity No. & Date c & cquisition & UTC Time & Path/ row & Processing level \\
\hline 1. & LT51880571986017AAA04 & $17-01$ & 86 & $09: 12$ & $188 / 057$ & L1T \\
\hline 2. & LT51880571986065XXX01 & $06-03$ & & 09:11 & $188 / 057$ & L1T \\
\hline 3. & LT51880571986353XXX10 & $19-12$ & & 09:04 & $188 / 057$ & $\mathrm{~L} 1 \mathrm{~T}$ \\
\hline 4. & LT51880571987004XXX04 & 04-01 & & 09:04 & $188 / 057$ & $\mathrm{~L} 1 \mathrm{~T}$ \\
\hline 5. & LT51880571987084XXX02 & $25-03$ & & 09:07 & $188 / 057$ & L1T \\
\hline 6. & LT51880571990356XXX03 & $22-12$ & & 09:10 & $188 / 057$ & $\mathrm{~L} 1 \mathrm{~T}$ \\
\hline 7. & LT51880571991007XXX03 & 07-01 & & 09:09 & $188 / 057$ & $\mathrm{~L} 1 \mathrm{~T}$ \\
\hline 8. & LE71880571999317EDC00 & $13-11$ & & $09: 38$ & $188 / 057$ & L1T \\
\hline 9. & LE71880572000352EDC00 & $17-12$ & & $09: 35$ & $188 / 057$ & $\mathrm{~L} 1 \mathrm{~T}$ \\
\hline 10. & LE71880572004331ASNO0 & $26-11$ & & $09: 34$ & $188 / 057$ & L1T \\
\hline 11. & LE71880572005029ASNO0 & $29-01$ & & $09: 34$ & $188 / 057$ & L1T \\
\hline 12. & LE71880572005365ASN00 & $31-12$ & & $09: 34$ & $188 / 057$ & L1T \\
\hline 13. & LE71880572006352ASN00 & $18-12$ & & $09: 35$ & $188 / 057$ & $\mathrm{~L} 1 \mathrm{~T}$ \\
\hline 14. & LE71880572007003ASN00 & $03-01$ & & $09: 35$ & $188 / 057$ & L1T \\
\hline 15. & LE71880572007355ASN00 & $21-12$ & & $09: 35$ & $188 / 057$ & L1T \\
\hline 16. & LE71880572008006ASN00 & 06-01 & & $09: 35$ & $188 / 057$ & $\mathrm{~L} 1 \mathrm{~T}$ \\
\hline 17. & LE71880572008326ASN00 & $21-11$ & & $09: 34$ & $188 / 057$ & $\mathrm{~L} 1 \mathrm{~T}$ \\
\hline 18. & LE71880572009344ASN00 & $10-12$ & & $09: 36$ & $188 / 057$ & L1T \\
\hline 19. & LE71880572010043ASNO0 & $12-02$ & & $09: 37$ & $188 / 057$ & $\mathrm{~L} 1 \mathrm{~T}$ \\
\hline 20. & LE71880572010347ASN00 & $13-12$ & & $09: 38$ & $188 / 057$ & $\mathrm{~L} 1 \mathrm{~T}$ \\
\hline 21. & LE71880572011334ASNO0 & $30-11$ & & $09: 38$ & $188 / 057$ & $\mathrm{~L} 1 \mathrm{~T}$ \\
\hline 22. & LE71880572011350ASN00 & $16-12$ & & 09:39 & $188 / 057$ & L1T \\
\hline 23. & LE71880572012017ASN00 & $17-01$ & 12 & 09:39 & $188 / 057$ & L1T \\
\hline 24. & LE71880572013003ASN00 & 03-01 & & 09:41 & $188 / 057$ & L1T \\
\hline 25. & LE71880572013067ASN00 & $08-03$ & & $09: 41$ & $188 / 057$ & $\mathrm{~L} 1 \mathrm{~T}$ \\
\hline
\end{tabular}


Landsat 5 Thematic Mapper (TM) and 18 data of Landsat 7 Enhanced Thematic Mapper Plus (ETM+) dated 17/01/1986 to 08/03/2013 used were downloaded from the USGS Earth Resources Observation and Science (EROS) Data Centre website (http://earthexplorer.usgs.gov/) using the Glovis/Earth Explorer interface. The scenes with $<5 \%$ contamination were selected for the research (Table 2); and all sites are located within a single Landsat scene (Path 188, Row 057). Landsat 5 TM images are acquired in 7 spectral bands while Landsat 7 ETM+ is acquired in 8 spectral bands; and both have similar spatial resolution of $30 \mathrm{~m}$ for bands $1-5$ and 7 . Band 8 for Landsat 7 ETM+ is panchromatic with a spatial resolution of $15 \mathrm{~m}$. The spatial resolution for Landsat 5 TM band 6 (Thermal infrared) is $120 \mathrm{~m}$ while for Landsat 7 ETM+ is $60 \mathrm{~m}$ but both are resampled to $30 \mathrm{~m}$ pixels (Morakinyo, 2015; Chander and Markham, 2003). L1T is the processing level for all the imagery, which means systematic radiometric and geometric correction using ground control points (GCPs), and digital elevation model (DEM) has been applied. The problem of Scan Line
Correction (SLC-off mode) with Landsat 7 sensor that started in 2004 which lead to loss of part of data in the imagery (Chen et al., 2012) was reduced to a minimum by setting one of the criteria for the selection of flare sites as the availability of data covering each facility.

\section{Meteorological Data}

Port Harcourt International Airport meteorological station which is about $50 \mathrm{~km}$ away from Eleme Refinery I Petroleum Company flaring site is the closest meteorological station available in Rivers State and its data is used in this research. The monthly wind directions and wind speeds data observed at $10 \mathrm{~m}$ height from 2000 to 2020 (21 years), collected from the Nigeria Meteorological Agency (NMA), Lagos, Nigeria were used in this study. South is the dominant wind origin direction, followed by the West direction with a few instances of South-West, North-West and North-East directions. Tables 3 and 4 shows the monthly wind directions and wind speeds measured at Port Harcourt International Airport meteorological station from 2000 to 2020.

\begin{tabular}{|c|c|c|c|c|c|c|c|c|c|c|c|c|c|}
\hline Stn & $\mathrm{Yr}$ & $\mathrm{J}$ & $F$ & $M$ & $\bar{A}$ & $\mathrm{M}$ & $\mathrm{J}$ & $\mathrm{J}$ & $\mathrm{A}$ & $\mathrm{S}$ & $\mathrm{O}$ & $\mathrm{N}$ & $\mathrm{D}$ \\
\hline $\mathrm{PH}$ & 2000 & $\mathrm{~S}$ & $\mathrm{~S}$ & $\mathrm{~S}$ & $\mathrm{~S}$ & $\mathrm{~S}$ & $\mathrm{~S}$ & SW & SW & SW & $\mathrm{S}$ & $\mathrm{S}$ & NW \\
\hline PH & 2001 & NW & $S$ & $\mathrm{~S}$ & $\mathrm{~S}$ & $\mathrm{~S}$ & $\mathrm{~S}$ & S & SW & W & $\mathrm{S}$ & $\mathrm{S}$ & NW \\
\hline $\mathrm{PH}$ & 2002 & NW & $S$ & $\mathrm{~S}$ & $S$ & $S$ & $\mathrm{~S}$ & $S$ & SW & SW & $S$ & $S$ & SW \\
\hline PH & 2003 & $\mathrm{~S}$ & $S$ & $\mathrm{~S}$ & $\mathrm{~S}$ & $\mathrm{~S}$ & $\mathrm{~S}$ & $S$ & S & W & W & S & S \\
\hline PH & 2004 & $S$ & $\mathrm{~N}$ & $\mathrm{~S}$ & $S$ & $S$ & $\mathrm{~S}$ & $S$ & W & W & $\mathrm{S}$ & S & W \\
\hline PH & 2005 & W & W & $\mathrm{S}$ & $\mathrm{S}$ & $\mathrm{S}$ & $\mathrm{S}$ & $S$ & W & $\mathrm{S}$ & $\mathrm{S}$ & $\mathrm{S}$ & W \\
\hline $\mathrm{PH}$ & 2006 & W & SW & $\mathrm{S}$ & $\mathrm{S}$ & $\mathrm{S}$ & $\mathrm{S}$ & $S$ & $S$ & SW & $\mathrm{S}$ & SW & W \\
\hline PH & 2007 & W & W & W & W & W & W & W & W & W & W & W & $\mathrm{NE}$ \\
\hline PH & 2008 & $\mathrm{~S}$ & $\mathrm{~N}$ & $\mathrm{~S}$ & $\mathrm{~S}$ & $\mathrm{~S}$ & $\mathrm{~S}$ & $S$ & W & W & $\mathrm{S}$ & S & W \\
\hline PH & 2009 & W & W & $\mathrm{S}$ & $\mathrm{S}$ & $\mathrm{S}$ & $\mathrm{S}$ & $S$ & W & $\mathrm{S}$ & $\mathrm{S}$ & S & W \\
\hline PH & 2010 & W & SW & $\mathrm{S}$ & $\mathrm{S}$ & $S$ & $\mathrm{~S}$ & $S$ & $\mathrm{~S}$ & SW & $\mathrm{S}$ & SW & W \\
\hline PH & 2011 & W & $S$ & $\mathrm{~S}$ & W & $\mathrm{S}$ & $\mathrm{S}$ & $S$ & W & W & $\mathrm{S}$ & $\mathrm{S}$ & W \\
\hline PH & 2012 & S & S & $\mathrm{S}$ & $\mathrm{S}$ & $\mathrm{S}$ & $\mathrm{S}$ & S & S & W & $\mathrm{S}$ & W & S \\
\hline PH & 2013 & $\mathrm{~S}$ & $S$ & $\mathrm{~S}$ & $\mathrm{~S}$ & $\mathrm{~S}$ & $\mathrm{~S}$ & $S$ & $S$ & W & $\mathrm{S}$ & S & W \\
\hline PH & 2014 & $\mathrm{~S}$ & $S$ & $\mathrm{~S}$ & W & $\mathrm{S}$ & $\mathrm{S}$ & SW & SW & SW & $\mathrm{S}$ & $S$ & W \\
\hline PH & 2015 & $S$ & SW & $\mathrm{S}$ & $\mathrm{S}$ & $\mathrm{S}$ & $\mathrm{S}$ & $S$ & S & W & $\mathrm{S}$ & S & $\mathrm{S}$ \\
\hline PH & 2016 & W & $\mathrm{S}$ & $\mathrm{S}$ & $\mathrm{S}$ & $S$ & $\mathrm{~S}$ & $\mathrm{~S}$ & $S$ & W & W & S & $\mathrm{S}$ \\
\hline PH & 2017 & W & $S$ & $\mathrm{~S}$ & $\mathrm{~S}$ & $S$ & $\mathrm{~S}$ & $S$ & S & S & $\mathrm{S}$ & W & W \\
\hline PH & 2018 & $\mathrm{~S}$ & S & $\mathrm{S}$ & $\mathrm{S}$ & W & $\mathrm{S}$ & S & SW & $S$ & $\mathrm{~S}$ & $\mathrm{~S}$ & W \\
\hline $\mathrm{PH}$ & 2019 & NW & $S$ & $\mathrm{~S}$ & $\mathrm{~S}$ & $\mathrm{~S}$ & $\mathrm{~S}$ & $S$ & W & $S$ & $S$ & $S$ & SW \\
\hline PH & 2020 & $S$ & NW & $\mathrm{S}$ & $\mathrm{S}$ & $\mathrm{S}$ & $\mathrm{S}$ & W & $\mathrm{S}$ & SW & $\mathrm{S}$ & SW & $\mathrm{S}$ \\
\hline
\end{tabular}

Table 4: Wind speed (m/s) at Port Harcourt International Airport, Rivers State (2000-2020).

\begin{tabular}{|c|c|c|c|c|c|c|c|c|c|c|c|c|c|}
\hline Stn & $\mathrm{Yr}$ & $\mathrm{J}$ & $\mathrm{F}$ & $\bar{M}$ & $\mathrm{~A}$ & M & $\mathrm{J}$ & $\mathrm{J}$ & $\mathrm{A}$ & $S$ & $\mathrm{O}$ & $\mathrm{N}$ & $\mathrm{D}$ \\
\hline $\mathrm{PH}$ & 2000 & 3.6 & 4.4 & 3.3 & 3.5 & 3.4 & 3.9 & 3.3 & 4.5 & 3.3 & 2.9 & 3.5 & 2.5 \\
\hline $\mathrm{PH}$ & 2001 & 4.1 & 4.5 & 4.3 & 3.6 & 3.7 & 2.9 & 2.2 & 3.3 & 2.3 & 1.0 & 1.7 & 2.2 \\
\hline $\mathrm{PH}$ & 2002 & 4.1 & 3.8 & 3.9 & 4.0 & 3.3 & 3.0 & 3.2 & 3.5 & 2.5 & 1.7 & 1.7 & 2.6 \\
\hline $\mathrm{PH}$ & 2003 & 2.8 & 2.6 & 3.1 & 2.7 & 2.8 & 3.5 & 3.9 & 2.7 & 3.0 & 2.0 & 2.0 & 2.4 \\
\hline $\mathrm{PH}$ & 2004 & 3.0 & 3.3 & 3.2 & 2.9 & 3.9 & 4.5 & 4.7 & 2.9 & 3.2 & 2.6 & 2.5 & 2.4 \\
\hline $\mathrm{PH}$ & 2005 & 3.8 & 4.4 & 5.5 & 4.6 & 4.1 & 4.3 & 4.7 & 5.5 & 4.5 & 3.8 & 2.8 & 3.3 \\
\hline $\mathrm{PH}$ & 2006 & 3.3 & 4.1 & 4.2 & 4.3 & 4.8 & 4.7 & 5.4 & 5.6 & 4.7 & 2.5 & 1.9 & 2.2 \\
\hline $\mathrm{PH}$ & 2007 & 2.4 & 3.9 & 4.1 & 4.6 & 4.1 & 4.7 & 4.5 & 4.7 & 3.7 & 3.3 & 2.7 & 2.8 \\
\hline $\mathrm{PH}$ & 2008 & 3.3 & 3.8 & 3.2 & 2.4 & 2.3 & 2.2 & 2.2 & 2.4 & 1.9 & 2.1 & 1.6 & 1.5 \\
\hline $\mathrm{PH}$ & 2009 & 5.3 & 2.3 & 2.3 & 2.6 & 2.3 & 2.6 & 3.5 & 2.1 & 2.3 & 2.8 & 2.2 & 1.8 \\
\hline $\mathrm{PH}$ & 2010 & 3.2 & 3.5 & 3.5 & 2.9 & 3.7 & 4.2 & 4.5 & 3.1 & 2.3 & 4.5 & 4.0 & 3.3 \\
\hline $\mathrm{PH}$ & 2011 & 3.1 & 3.4 & 3.3 & 3.0 & 4.0 & 4.6 & 4.7 & 3.0 & 3.3 & 2.7 & 2.6 & 2.5 \\
\hline $\mathrm{PH}$ & 2012 & 3.4 & 3.9 & 3.3 & 2.5 & 2.4 & 2.3 & 2.3 & 2.5 & 2.0 & 2.2 & 1.7 & 1.6 \\
\hline $\mathrm{PH}$ & 2013 & 3.2 & 4.0 & 4.1 & 4.2 & 4.7 & 4.6 & 5.3 & 5.5 & 4.6 & 2.4 & 1.8 & 2.1 \\
\hline $\mathrm{PH}$ & 2014 & 4.0 & 4.4 & 4.2 & 3.5 & 3.6 & 2.8 & 2.1 & 3.2 & 2.2 & 1.0 & 1.6 & 2.2 \\
\hline $\mathrm{PH}$ & 2015 & 3.2 & 3.4 & 3.5 & 3.0 & 3.6 & 4.1 & 4.4 & 3.1 & 2.4 & 4.4 & 3.9 & 3.3 \\
\hline $\mathrm{PH}$ & 2016 & 3.5 & 4.4 & 3.4 & 3.6 & 3.4 & 3.8 & 3.4 & 4.3 & 3.4 & 2.8 & 3.4 & 2.5 \\
\hline $\mathrm{PH}$ & 2017 & 2.9 & 2.7 & 3.2 & 2.8 & 2.9 & 3.4 & 3.8 & 2.8 & 3.1 & 2.2 & 2.2 & 2.5 \\
\hline $\mathrm{PH}$ & 2018 & 2.5 & 3.8 & 4.0 & 4.5 & 4.0 & 4.5 & 4.4 & 4.5 & 3.7 & 3.3 & 2.8 & 2.9 \\
\hline $\mathrm{PH}$ & 2019 & 5.2 & 2.4 & 2.5 & 2.6 & 2.4 & 2.6 & 3.4 & 2.2 & 2.4 & 2.9 & 2.3 & 2.1 \\
\hline $\mathrm{PH}$ & 2020 & 4.2 & 3.9 & 4.0 & 4.1 & 3.5 & 3.1 & 3.3 & 3.6 & 2.7 & 1.9 & 1.9 & 2.8 \\
\hline
\end{tabular}


Methods

Processing Steps for Landsat 5 TM and Landsat 7 ETM+ Data

The methods adopted are:

(1). Verification of geo-location points using Google Earth. 5 ground control points each were selected over all the 11 sites and measured with GPS on site during ground validation exercise. 14 imagery (7 each from Landsat 5 TM and Landsat 7 ETM+) were uploaded into ArcGIS and the selected ground control points (GCPs) were identified.

(2) MATLAB code was used for data processing and for removal of zero or out of range values from the data and their replacement with not a number (nan) to avoid divide by zero errors in calculations.

(3) Radiometric calibration of the thermal band (6) of the data by converting the Digital Number (DN) values recorded into top of atmosphere (TOA) radiance or temperature values based on sensor calibration parameters provided within the metadata files from USGS (Chander and Markham, 2003; NASA, 2002) using equation 1

$\mathrm{L}_{\lambda}=\left(\left(\mathrm{LMAX}_{\lambda}-\mathrm{LMIN}_{\lambda}\right) /\left(\mathrm{QCALMAX}^{-}\right.\right.$QCALMIN $\left.)\right)$ $\times(\mathrm{QCAL}-\mathrm{QCALMIN})+\mathrm{LMIN}_{\lambda}$ (Eq.1)

Where:

$\mathrm{L}_{\lambda}=$ Spectral Radiance at the sensor's aperture $\left(\mathrm{Wm}^{-2} \mathrm{sr}^{-1} \mu \mathrm{m}^{-1}\right)$;

$\mathrm{QCAL}=$ The quantized calibrated pixel value in $\mathrm{DN}$; $\operatorname{LMIN}_{\lambda}=$ The spectral radiance that is scaled to QCALMIN $\left(\mathrm{Wm}^{-2} \mathrm{sr}^{-1} \mu \mathrm{m}^{-1}\right)$;

$\operatorname{LMAX}_{\lambda}=$ The spectral radiance that is scaled to QCALMAX $\left(\mathrm{Wm}^{-2} \mathrm{sr}^{-1} \mu \mathrm{m}^{-1}\right)$;

QCALMIN $=$ The minimum quantized calibrated pixel value (corresponding to $\operatorname{LMIN}_{\lambda}$ ) in DN $=1$ for LPGS (a processing software version) products;

QCALMAX $=$ The maximum quantized calibrated pixel value (corresponding to $\mathrm{LMAX}_{\lambda}$ ) in $\mathrm{DN}=255$.

(4) Removing atmospheric effects from multispectral bands (1-4) and thermal band (6). The atmospheric correction parameters (upwelling radiance $\left(\mathrm{L}_{\mathrm{u}}\right)$, downwelling radiance $\left(\mathrm{L}_{\mathrm{d}}\right)$, and transmittance $(\tau)$ ) obtained from Atmospheric Correction Parameters (ATMCORR) Calculator, a National Aeronautics and Space Administration (NASA) web tool developed by Barsi et al. (2005), were applied to thermal band 6 to obtain atmospherically corrected data. Dark Object Subtraction (DOS) method (Kaufman et al., 2000) was employed for removing atmospheric effects from the multispectral bands (1-4).

Land Use Land Cover (LULC) Classification and Estimation of Emissivity $(\varepsilon)$ Values

4 land cover (LC) types (vegetation, soil, built up and water) (Maaharjan, 2018) with their \% identified at study sites during ground validation from 04/08/201221/09/2012 and 05/08/2020- 21/09/2020 was derived when MATLAB code and cluster analysis method (Şatır and Berberoğlu, 2012) were applied to the atmospherically corrected reflectance (bands 1-4) produced by Landsat $5 \mathrm{TM}$ and Landsat 7 ETM+ (Alvarez, 2009). The 4 LC types was clarified using images held within Google Earth and Digital Global (http://browse.digitalglobe.com/imagefinder/public.do) such as WorldView-1 and 2, IKONOS pseudo-true colour images, Landsat imagery (bands 1-4 and 6), and Red, Green, Blue (RGB) pseudo-true colour composite images.

The method adopted to estimate emissivity $(\varepsilon)$ value for LC types at the sites is based on the $\varepsilon$ value of $4 \mathrm{LC}$ types present at each site. Each pixel LC types were considered for the entire site and their $\varepsilon$ values (both minimum (min) and maximum $(\max )$ ) were taken from the literature. Mean of $\varepsilon$ values for LC types for each single pixel obtained from using their ( $\min )$ and (max) values from the literature were calculated. Average of both $(\min )$ and $(\max ) \varepsilon$ values results were obtained for each pixel and the same procedure was repeated for all pixels in the selected $12 \times 12 \mathrm{~km}$ area (Morakinyo, et al., 2019). Therefore, the $\varepsilon$ value for each Landsat pixel's LC is a combination of the $\varepsilon$ value of background features present within the pixel. The authors adopted an independent method of using LC types at each site for the correction of $\varepsilon$ value rather than Global Land Cover (GLC) data from USGS in order to ensure quality control primarily.

Retrieval of LST from atmospherically corrected Landsat 5 TM and Landsat 7 ETM+ datasets.

The theoretical basis for the LST measurement is Plank's radiation function, formulated as:

$$
\mathrm{B}(\lambda, \mathrm{T})=\frac{\mathrm{C}_{1} \lambda^{-5}}{\pi\left(\exp \left(\mathrm{C}_{2} / \lambda \mathrm{T}\right)-1\right)}
$$

Where:

$\mathrm{B}(\lambda, \mathrm{T})=$ Spectral radiance of a blackbody $\left(\mathrm{Wm}^{-2} \mathrm{sr}\right.$ $\left.{ }^{1} \mu \mathrm{m}^{-2}\right) ; \lambda=$ Wavelength $(\mathrm{m})$;

$\mathrm{T}=$ Temperature $(\mathrm{K}) ; \mathrm{C}_{1}=$ The first spectral constant $=$ $3.741775 \times 10^{-22} \mathrm{Wm}^{2}$;

$\mathrm{C}_{2}=$ The second spectral constant $1.4388 \times 10^{-2} \mathrm{mK}$; PI $(\pi)=$ constant $=3.142$ (Qin et al., 2011).

When $\mathrm{B}(\lambda, T)$ is measured generally by a thermal sensor, the surface-leaving radiance $\left(\mathrm{L}_{\lambda}\right)$ can be computed by inverting the Planck's radiance function as follows (Figure 3):

$$
\mathrm{L}_{\lambda}=\frac{\mathrm{C}_{2}}{\lambda \ln \left[\left(\mathrm{C}_{1} / \lambda^{5} \mathrm{~B}(\lambda, \mathrm{T})\right)+1\right]} \quad \text { (Eq. 3) }
$$

The approach for the calculation of LST, by first calculating $\mathrm{L}_{\lambda}$ and substituting it into the Planck function and inverting the function to get the LST was adopted for the study (Figure 3) (Morakinyo, 2020a; Coll et al., 2010). The formula for computing $\mathrm{L}_{\lambda}$ is: $\mathrm{L}_{\lambda}=\left(\left(\mathrm{L}_{\mathrm{s}}-\mathrm{L}_{\mathrm{u}}\right) / \varepsilon \tau\right)-((1-\varepsilon) / \varepsilon) \times \mathrm{L}_{\mathrm{d}}\left(\mathrm{Wm}^{-2} \mathrm{sr}^{-1} \mu \mathrm{m}^{-1}\right)$ (Eq. 4) 
The $\mathrm{L}_{\mathrm{u}}, \mathrm{L}_{\mathrm{d}}$, and $\tau$ were applied to the calibrated at-sensor radiance band 6 (High gain) data to compute the $\mathrm{L}_{\lambda}$.

Where,

$\mathrm{L}_{\mathrm{s}}=$ Radiometrically corrected Landsat thermal band 6 radiance (High gain);

$\mathrm{L}_{\mathrm{u}}=$ Upwelling radiance; $\mathrm{L}_{\mathrm{d}}=$ Downwelling radiance; $\tau=$ Atmospheric transmission; $\varepsilon=$ emissivity.

$\mathrm{L}_{\mathrm{u}}, \mathrm{L}_{\mathrm{d}}$, and $\tau$ are atmospheric correction parameters for the Landsat thermal band.
LST was derived using equation 5.

$\mathrm{LST}=\frac{\mathrm{K}_{2}}{\ln \left(\left(\mathrm{K}_{1} / \mathrm{L}_{\lambda}\right)+1\right)}$

Where, $\mathrm{K}_{1}$ and $\mathrm{K}_{2}$ are thermal band calibration constants calculated for the Landsat sensor characteristics.

For Landsat $5 \mathrm{TM}, \mathrm{K}_{1}=607.76\left(\mathrm{Wm}^{-2} \mathrm{sr}^{-1} \mu \mathrm{m}^{-1}\right)$ and $\mathrm{K}_{2}=$ $1260.56(\mathrm{~K})$; and

For Landsat $7 \mathrm{ETM}+, \mathrm{K}_{1}=666.09\left(\mathrm{~W} \mathrm{~m}^{-2} \mathrm{sr}^{-1} \mu \mathrm{m}^{-1}\right)$ and $\mathrm{K}_{2}=1282.71(\mathrm{~K})$.

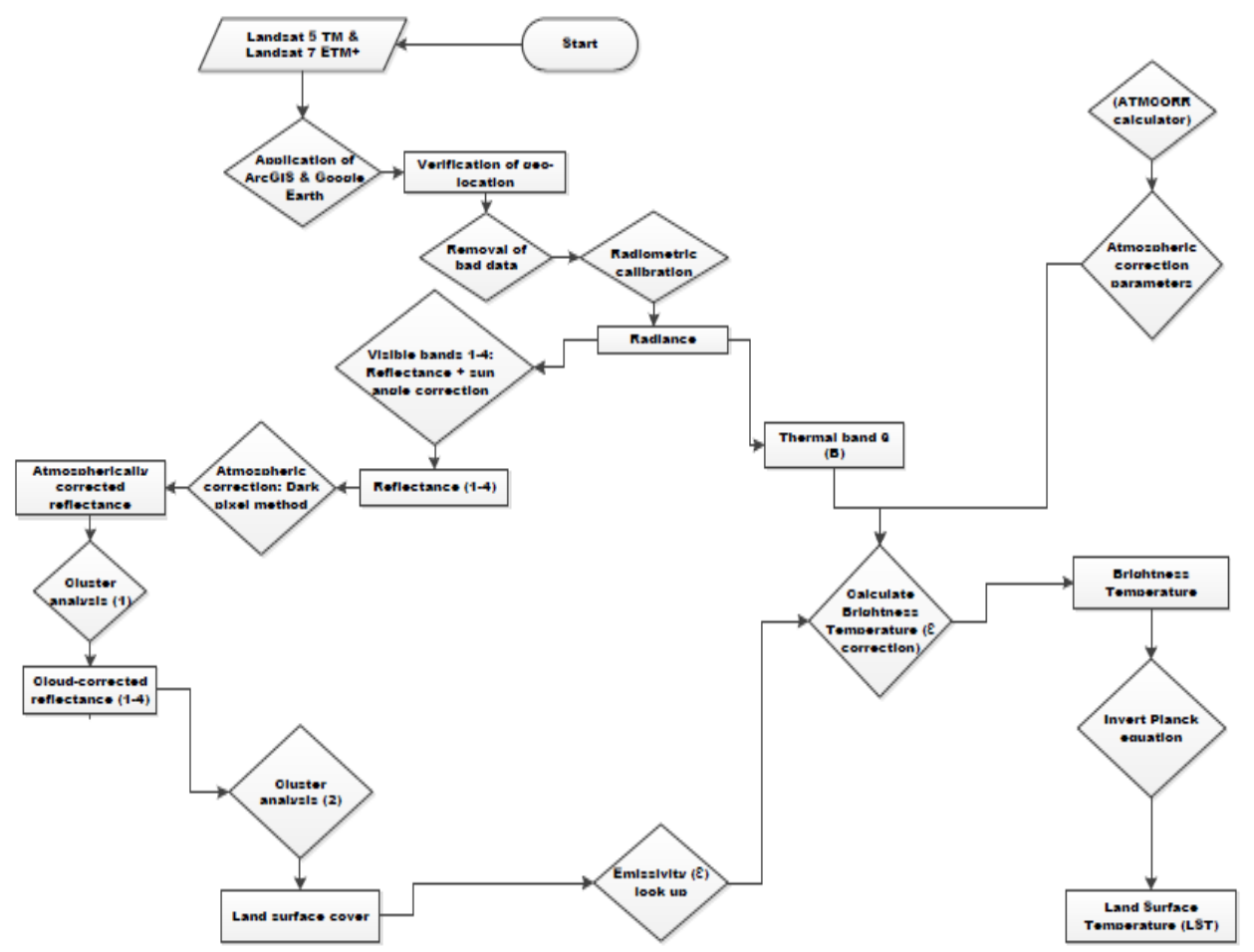

Fig. 3: Flowchart presentation of the methods employed for the processing of Landsat 5 TM and Landsat 7 ETM+ data for LULC classification, estimation of emissivity and LST retrieval.

\section{Linear regression analysis of $\delta L S T_{N, S, E, W}$}

Linear regression helps to model the relationship between two variables by fitting a linear equation to observed data. Linear regression analysis is the most widely used of all statistical techniques: it is the study of linear, additive relationships between variables (Eze et al., 2005). One variable is considered to be an independent variable, and the other is considered to be a dependent variable. A scatter plot (Figure 8) is a helpful tool in determining the strength of the relationship between two variables. If there appears to be no relationship between the proposed independent and dependent variables (i.e., the scatter plot does not indicate any increasing or decreasing trends), then fitting a linear regression model to the data probably will not provide a useful model. A valuable numerical measure of relationship between two variables is the correlation coefficient, which is a value between -1 and 1 indicating the strength of the relationship of the observed data for the two variables. A linear regression line has an equation of the form $\mathrm{Y}=\mathrm{a}+\mathrm{bX}$, where $\mathrm{X}=$ Independent variable and $\mathrm{Y}=$ Dependent variable, $\mathrm{b}=$ Slope of the line and $\mathrm{a}=$ Intercept (the value of $\mathrm{Y}$ when $\mathrm{X}=0$ ) (Eze et al., 2005).
A new parameter $\delta$ LST was defined to facilitate quantitative verification of the heat sources at the flare locations. $\delta \mathrm{LST}$ is the difference between the LST at the flare stack and the LST at $450 \mathrm{~m}$ (maximum distance) from the flare stack. Figure 4 shows the schematic diagram for the definition of $\delta \mathrm{LST}$.

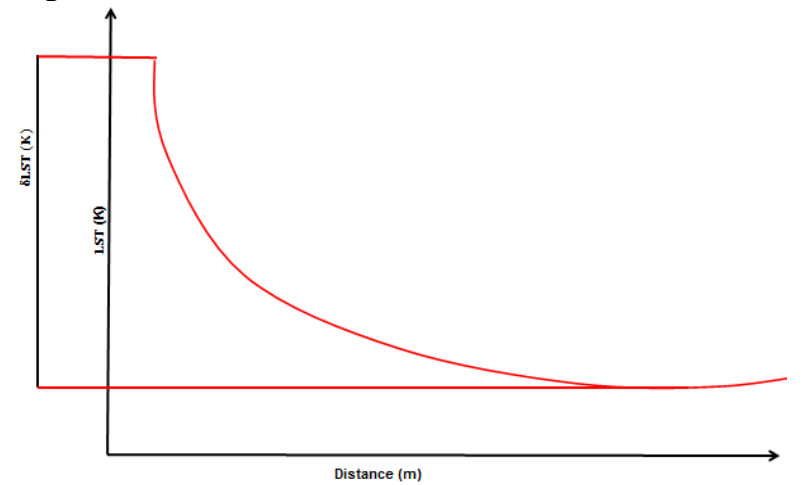

Fig. 4: Change in LST with distance, and the definition of $\delta$ LST

Both linear and non-linear relationships were tested, but non-linear give no better results. Hence, linear regression analysis was used to compare $\delta$ LST in different 
directions at the flaring sites. Specifically, it was assumed that a consistent relationship should exist between $\delta$ LST in pairs of directions at any site where a strong prevailing wind does not influence the impact of the flare on LST values near the flare; i.e. heat from the flare radiates equally in all directions and the resulting heated air mass does not flow in a dominant direction. Pairwise linear regression analysis was applied to the
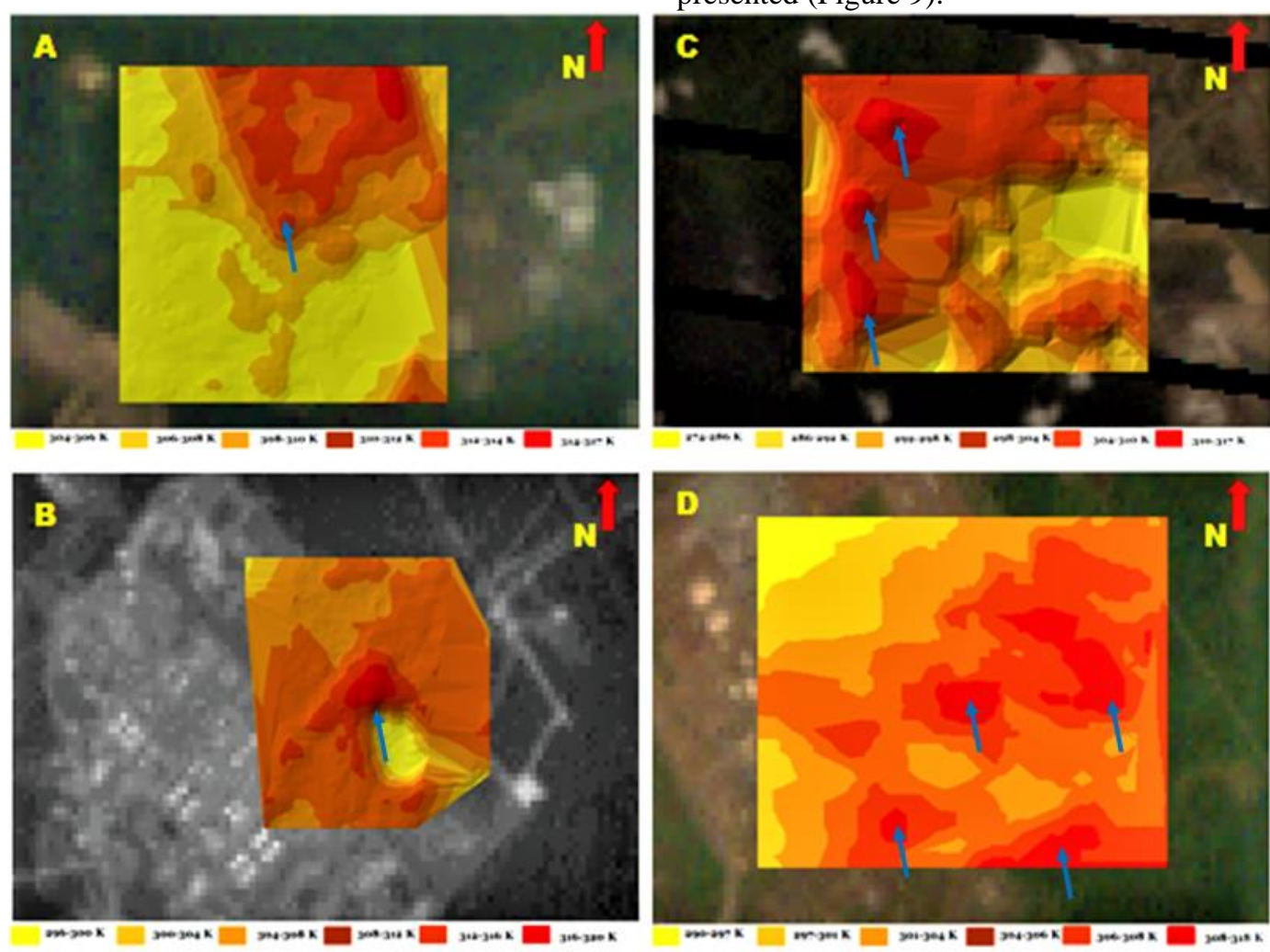

Fig. 5: A) Eleme Refinery I; B) Eleme Refinery II; C) Onne Flow Station; D) Umurolu Flow Station.
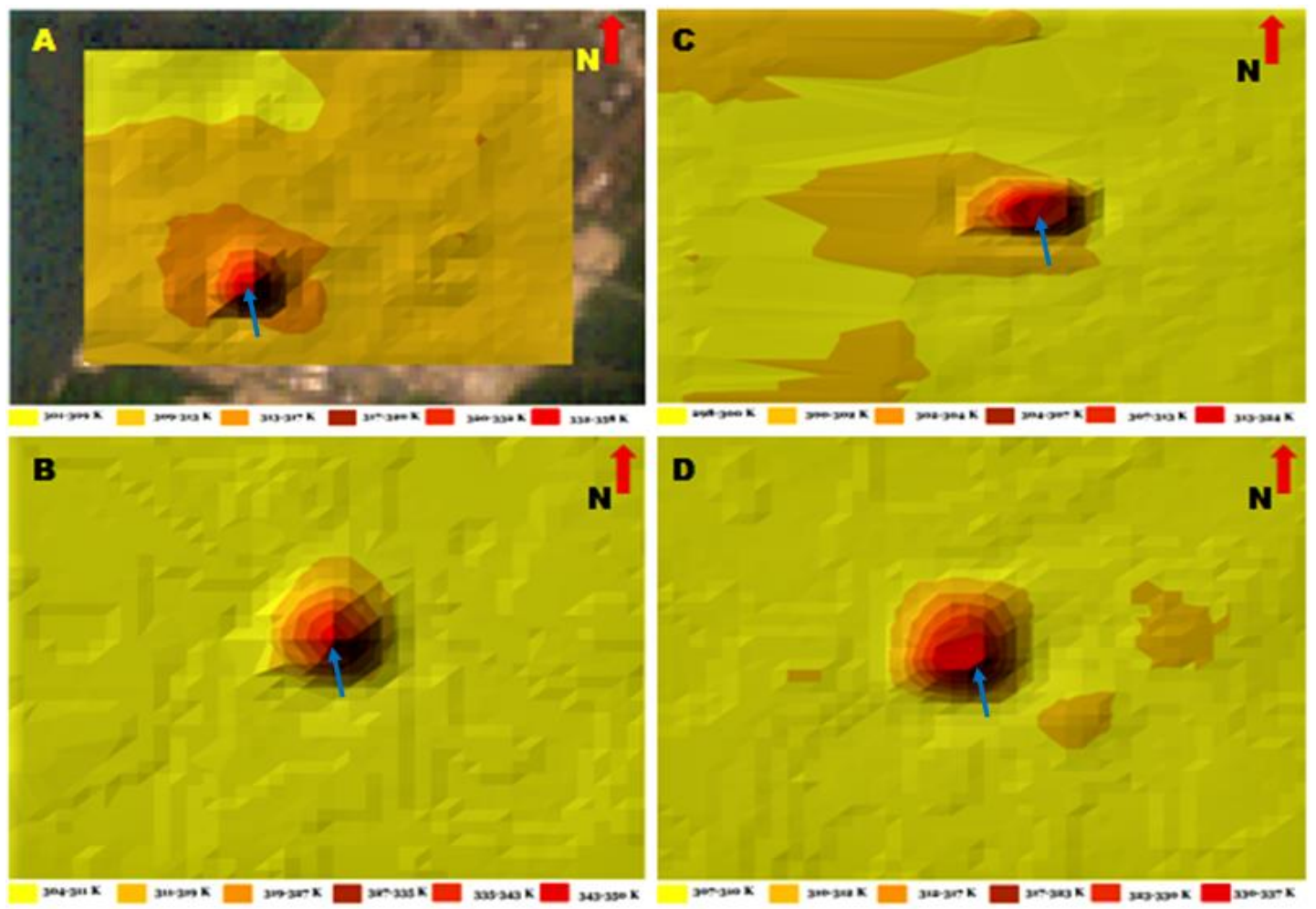

Fig. 6: A) Bonny LNG; B) Alua Flow Station; C) Rukpokwu Flow Station; D) Obigbo Flow Station. 


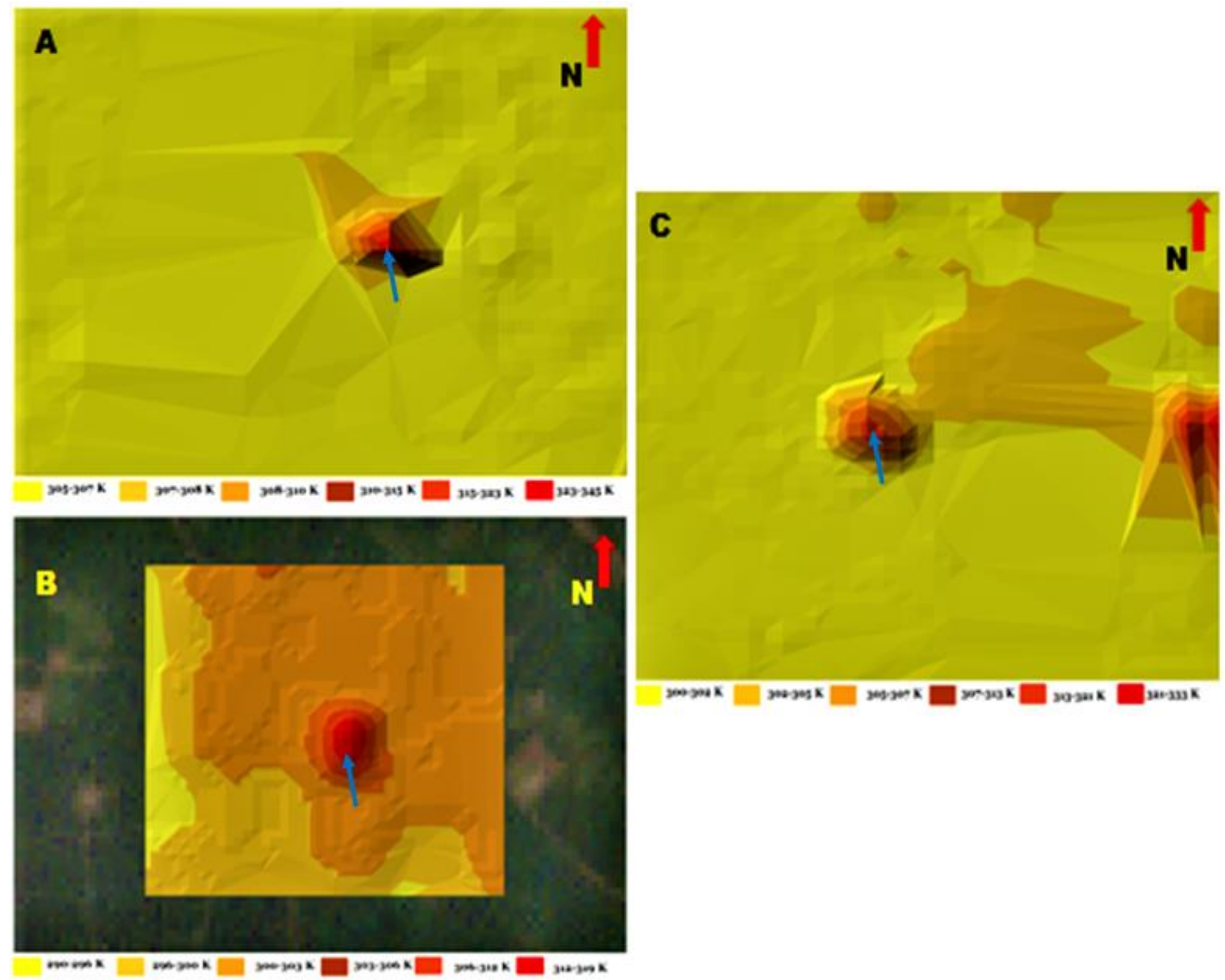

Fig. 7: A) Chokocho Flow Station; B) Umudioga Flow Station; C) Sara Flow Station.

Results and Discussion

Retrieval of LST from atmospherically corrected Landsat 5 TM and Landsat 7 ETM+ datasets.

For the Figures 5-7, the pseudo-true colour images from the combination of Landsat bands 3,2 and 1 as Red, Green and Blue (RGB) were used as the background map for the sites instead of the Google Earth images in order to avoid geo-referencing errors that are associated with Google Earth images. The Red arrow and letter $\mathrm{N}$ at the upper corner of the right side shows the direction of the North, the Blue arrow show the flare flack and Kelvin (K) in the legend is the International System Unit for temperature. Figures 5-7 show the 2D ArcGIS plots of each facility with LST overlaid and classified in 6 different range group layers with a colour to represent each group. Pure red colour is for highest range of values, followed by light red, light brown, deep orange, light orange and yellow colours respectively. This is to help in determining the best direction of the minimum and maximum LST slope for each site. Generally, for all sites, the spatial analysis of LST with ArcGIS shows that the flare sources give the highest LST, followed by the next adjoining pixels surrounding the flare and continue in that order.

For Eleme I and II refineries (Figures 5A and 5B), Onne and Umurolu Flow Stations (Figures 5C and 5D), their data acquisition dates, wind directions and wind speeds are 17/12/2000, North-West, $2.5 \mathrm{~m} / \mathrm{s} ; 29 / 01 / 2005$, South,
$3.8 \mathrm{~m} / \mathrm{s} ; 08 / 03 / 2013$, South, $4.1 \mathrm{~m} / \mathrm{s}$; and 12/02/2010, South, $3.5 \mathrm{~m} / \mathrm{s}$ respectively. Similarly, for Bonny LNG (Figure 6A), Alua, Rukpokwu and Obigbo Flow Stations (Figures 6B-6D), their acquisition dates, wind directions and wind speeds are 06/01/2008, South, $3.3 \mathrm{~m} / \mathrm{s}$; $16 / 12 / 2011$, South, $3.6 \mathrm{~m} / \mathrm{s} ; 10 / 12 / 2009$, West, $1.8 \mathrm{~m} / \mathrm{s}$; and 12/02/2010, South, $3.5 \mathrm{~m} / \mathrm{s}$ respectively. Also, the acquired dates, wind directions and wind speeds for Chokocho, Umudioga and Sara Flow Stations (Figures (7A-7C) are 03/01/2013, North-East, $3.2 \mathrm{~m} / \mathrm{s}$; 26/11/2004, South, $2.5 \mathrm{~m} / \mathrm{s}$; and 21/12/2007, West, 2.8 $\mathrm{m} / \mathrm{s}$ respectively.

Generally, it is observed that the size and shape of the plume, and LST differ from one oil facility to another. Therefore, the result suggests that the LST retrieved is dependent on the size of the facility, volume and rate of the burning gas at the time of satellite overpass.

\section{Linear regression analysis of $\delta L S T_{N, S, E, W}$}

All relationships with significant impact for each site are shown in bold in Table 5. Figure 8 summarize these results.

$\delta \mathrm{LST}_{\mathrm{NE}}=$ relationship between $\delta \mathrm{LST}_{\mathrm{N}}$ and $\delta \mathrm{LST}_{\mathrm{E}}$;

$\delta \mathrm{LST}_{\mathrm{NS}}=$ relationship between $\delta \mathrm{LST}_{\mathrm{N}}$ and $\delta \mathrm{LST}_{\mathrm{S}}$; $\delta \mathrm{LST}_{\mathrm{NW}}=$ relationship between $\delta \mathrm{LST}_{\mathrm{N}}$ and $\delta \mathrm{LST}_{\mathrm{W}}$.

Table 5 show a -correlation for $\delta \mathrm{LST}_{\mathrm{N}}$ compared to $\delta \mathrm{LST}_{\mathrm{E}}$, and a +correlation for both the $\delta \mathrm{LST}_{\mathrm{NS}}$ and $\delta \mathrm{LST}_{\mathrm{NW}}$ directions for Eleme Refinery I. Both Eleme II and Onne were characterized by +correlations for both 
the $\delta \mathrm{LST}_{\mathrm{NE}}$ and $\delta \mathrm{LST}_{\mathrm{NS}}$ directions, and a -correlation for the $\delta \mathrm{LST}_{\mathrm{NW}}$ direction. However, the p-values for both Eleme I and II, and Onne showed that no statistically significant relationships between $\delta \mathrm{LST}$ values in different directions existed. Umurolu, Bonny LNG, Alua, Rukpokwu, Chokocho and Sara were characterized by correlations amongst the 4 directions and their p-values showed that these were statistically significant. Obigbo and Umudioga had +correlations with 3 of the relationships; Obigbo had significant p- values for both $\delta \mathrm{LST}_{\mathrm{NE}}$ and $\delta \mathrm{LST}_{\mathrm{NW}}$ while Umudioga had significant $\mathrm{p}$-values for $\delta \mathrm{LST}_{\mathrm{NW}}$ only.

Table 6 presents another set of correlation coefficients $\left(\mathrm{r}^{2}\right.$-value and $\mathrm{p}$-value) for the 11 facilities with a condition that any $\delta$ LST with a p-value (computed from ANOVA) greater than $\alpha=0.01$ should not be used. The results in Table 6 suggests that the influence of South wind demonstrated in Table 5 is the same as recorded in Table 6 despite a further statistical condition imposed on the Table 5 results.

Table 5: Computed values of, $\mathrm{r}^{2}$ and p-value with $\boldsymbol{\alpha}=0.01$ from $\delta \mathrm{LST}_{\mathrm{N}}, \boldsymbol{\delta} \mathrm{LST}_{\mathrm{S}}, \boldsymbol{\delta} \mathrm{LST}_{\mathrm{E}}, \boldsymbol{\delta} \mathrm{LST}$ for each facility (using linear regression analysis and p-value)

\begin{tabular}{|c|c|c|c|c|c|c|c|}
\hline \multirow[t]{2}{*}{$\mathrm{S} / \mathrm{N}$} & \multirow[t]{2}{*}{ Facility } & \multicolumn{2}{|c|}{$\delta \mathrm{LST}_{\mathrm{NE}}$} & \multicolumn{2}{|c|}{$\delta \mathrm{LST}_{\mathrm{NS}}$} & \multicolumn{2}{|c|}{$\delta \mathrm{LST}_{\mathrm{NW}}$} \\
\hline & & $\mathrm{r}^{2}$ & $\mathrm{p}$-value & $r^{2}$ & $\mathrm{p}$-value & $\mathrm{r}^{2}$ & $\mathrm{p}$-value \\
\hline 1. & Eleme I & -0.0001 & 0.965 & 0.017 & 0.594 & 0.023 & 0.539 \\
\hline 2. & Eleme II & 0.0024 & 0.811 & 0.019 & 0.499 & $-3.611 \times 10^{-4}$ & 0.937 \\
\hline 3. & Onne & 0.074 & 0.080 & 0.046 & 0.172 & $-6.241 \times 10^{-3}$ & 0.619 \\
\hline 4. & Umurolu & 0.538 & $7.000 \times 10^{-8}$ & 0.206 & 0.003 & 0.642 & $5.470 \times 10^{-10}$ \\
\hline 5. & Bonny & 0.501 & $4.140 \times 10^{-6}$ & 0.377 & $\mathbf{1 . 4 6 5} \times 10^{-4}$ & 0.584 & $2.227 \times 10^{-7}$ \\
\hline 6. & Alua & 0.898 & $6.774 \times 10^{-15}$ & 0.753 & $1.123 \times 10^{-9}$ & 0.662 & $8.035 \times 10^{-8}$ \\
\hline 7. & Rukpokwu & $\mathbf{0 . 5 2 7}$ & $1.138 \times 10^{-7}$ & 0.753 & $1.123 \times 10^{-5}$ & 0.266 & $6.657 \times 10^{-4}$ \\
\hline 8. & Obigbo & 0.778 & $5.700 \times 10^{-10}$ & 0.200 & 0.017 & 0.272 & 0.004 \\
\hline 9. & Chokocho & 0.540 & $5.587 \times 10^{-6}$ & 0.221 & 0.010 & 0.805 & $4.444 \times 10^{-11}$ \\
\hline 10. & Umudioga & 0.261 & 0.015 & 0.125 & 0.106 & 0.343 & 0.004 \\
\hline 11. & Sara & 0.707 & $1.121 \times 10^{-11}$ & 0.196 & 0.004 & 0.461 & $1.448 \times 10^{-6}$ \\
\hline
\end{tabular}
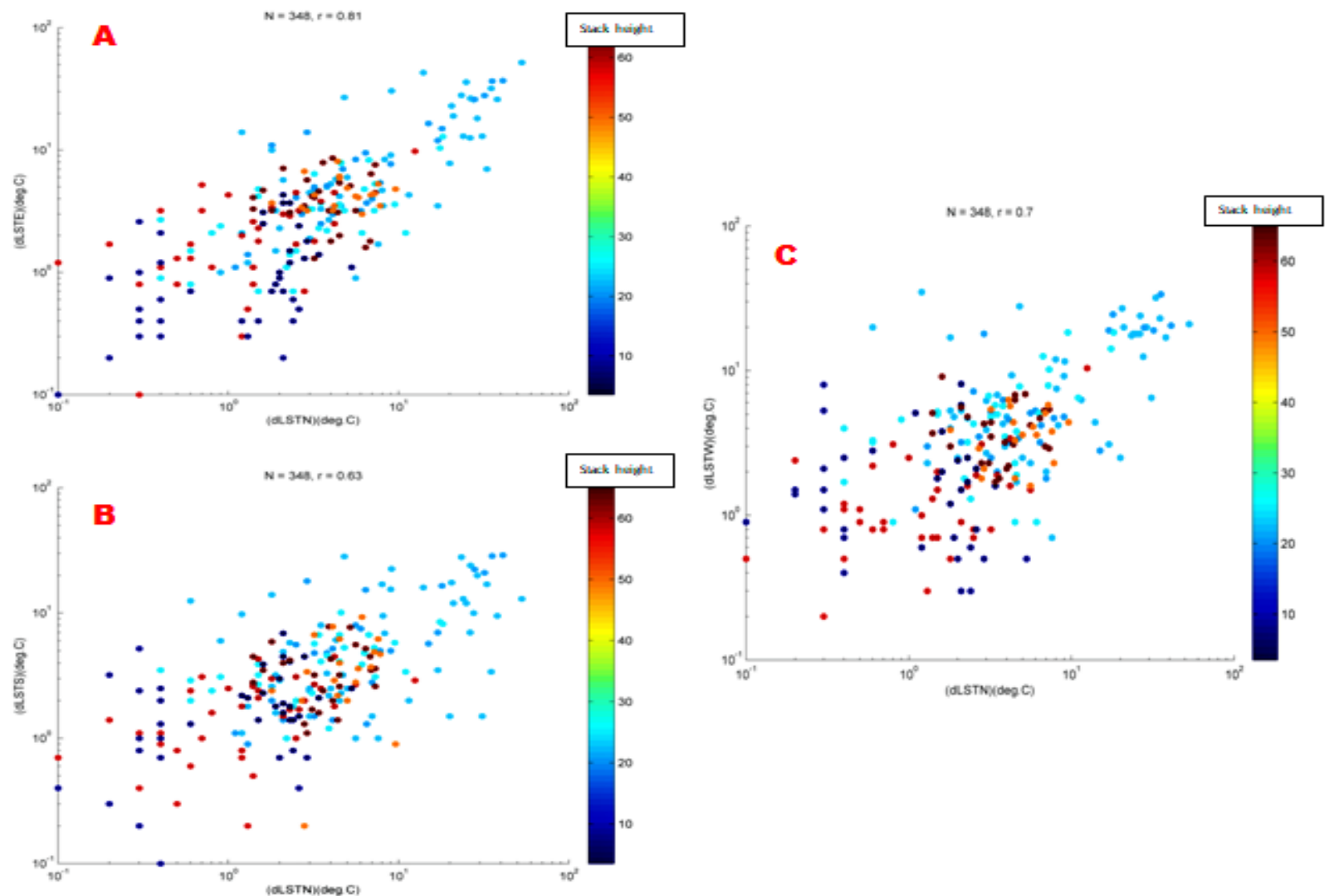

Fig. 8: A) $\boldsymbol{\delta} \mathrm{LST}_{\mathrm{N}}$ against $\boldsymbol{\delta} \mathrm{LST}_{\mathrm{E}}$; B) $\boldsymbol{\delta} \mathrm{LST}_{\mathrm{N}}$ against $\boldsymbol{\delta} \mathrm{LST}_{\mathrm{S}}$; C) $\boldsymbol{\delta} \mathrm{LST}_{\mathrm{N}}$ against $\boldsymbol{\delta} \mathrm{LST}_{\mathrm{W}}$ 
Table 6: Computed values of $\mathrm{r}^{2}$ and p-value for $\alpha=0.01$ from $\delta \mathrm{LST}_{\mathrm{N}}, \delta \mathrm{LST}_{\mathrm{E}}, \delta \mathrm{LST}_{\mathrm{s}}, \delta \mathrm{LST}_{\mathrm{W}}$ and each facility (using linear regression analysis, $\mathrm{p}$-value computed from ANOVA)

\begin{tabular}{|c|c|c|c|c|c|c|c|}
\hline \multirow[t]{2}{*}{$\mathrm{S} / \mathrm{N}$} & \multirow[t]{2}{*}{ Facility } & \multicolumn{2}{|r|}{$\delta \mathrm{LST}_{\mathrm{NE}}$} & \multicolumn{2}{|r|}{$\delta \mathrm{LST}_{\mathrm{NS}}$} & \multicolumn{2}{|r|}{$\delta \mathrm{LST}_{\mathrm{NW}}$} \\
\hline & & $\mathrm{r}^{2}$ & p-value & $\mathrm{r}^{2}$ & p-value & $\mathrm{r}^{2}$ & p-value \\
\hline 1. & Eleme I & 0.104 & 0.682 & 0.020 & 0.945 & -0.010 & 0.972 \\
\hline 2. & Eleme II & 0.043 & 0.860 & 0.268 & 0.298 & 0.119 & 0.649 \\
\hline 3. & Onne & 0.291 & 0.158 & 0.099 & 0.618 & -0.022 & 0.920 \\
\hline 4. & Umurolu & 0.804 & $8.789 \times 10^{-8}$ & 0.474 & 0.010 & 0.811 & $2.976 \times 10^{-7}$ \\
\hline 5. & Bonny & 0.760 & $1.584 \times 10^{-4}$ & 0.635 & 0.003 & 0.796 & $2.725 \times 10^{-5}$ \\
\hline 6. & Alua & 0.962 & $5.620 \times 10^{-11}$ & 0.908 & $8.008 \times 10^{-8}$ & 0.814 & $7.048 \times 10^{-6}$ \\
\hline 7. & Rukpokwu & 0.809 & $1.817 \times 10^{-7}$ & 0.605 & $3.142 \times 10^{-4}$ & 0.461 & 0.002 \\
\hline 8. & Obigbo & 0.886 & $9.233 \times 10^{-8}$ & 0.474 & 0.035 & 0.423 & 0.007 \\
\hline 9. & Chokocho & 0.794 & $1.019 \times 10^{-5}$ & 0.380 & 0.008 & 0.934 & $2.600 \times 10^{-11}$ \\
\hline 10. & Umudioga & 0.333 & 0.290 & 0.488 & 0.055 & 0.662 & $\mathbf{0 . 0 1 0}$ \\
\hline 11. & Sara & 0.910 & $1.123 \times 10^{-10}$ & 0.368 & 0.004 & 0.746 & $2.885 \times 10^{-5}$ \\
\hline
\end{tabular}
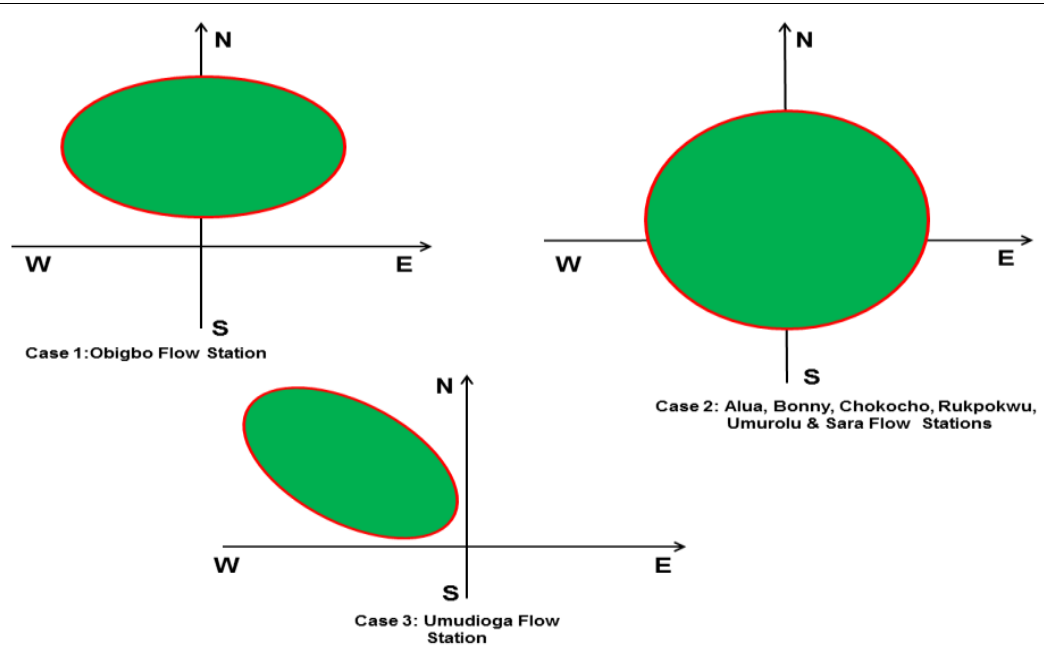

Fig. 9: Geographical symmetry of LST in relation to the flare

Furthermore, Figure 9 is the graphical representation of Table 6 in which 3 different cases are presented to summarize the spatial geographical shape of $\delta$ LST around the study sites. The figure for each case was created based on the facilities with statistically significant $\mathrm{p}$-value from any of the 3 relationships $\left(\delta \mathrm{LST}_{\mathrm{NE}} \delta \mathrm{LST}_{\mathrm{NS}}\right.$, and $\left.\delta \mathrm{LST}_{\mathrm{NW}}\right)$. For case 1 , Obigbo Flow Station only, the p-value for the pairwise linear regression of $\delta \mathrm{LST}_{\mathrm{N}}$ against $\delta \mathrm{LST}_{\mathrm{E}}$, and $\delta \mathrm{LST}_{\mathrm{N}}$ against $\delta \mathrm{LST}_{\mathrm{W}}$ are statistically significant. This shows that the wind direction (South) for data acquisition date used to plot Obigbo site, combined with the South prevailing wind to generate a noticeable impact on the LST towards the North-East and the North-West directions. Case 2 is for Alua, Bonny, Chokocho, Rukpokwu, Umurolu and Sara Flow Stations where there is no evidence of the influence of their respective wind directions for data acquisition dates, and that of the South prevailing wind on the flare because $\delta$ LST is directionally uniform; therefore, the flare $\delta$ LST footprint is a circle. The pvalue obtained is statistically significant for all the 3 $\left(\delta \mathrm{LST}_{\mathrm{NE}}, \delta \mathrm{LST}_{\mathrm{NS}}\right.$ and $\left.\delta \mathrm{LST}_{\mathrm{NW}}\right)$ relationships. For case 3 , which is for Umudioga site, only $\delta \mathrm{LST}_{\mathrm{N}}$ versus $\delta \mathrm{LST}_{\mathrm{W}}$ is statistically significant. The influence of the combination of the wind direction (South) for data acquisition date used for plotting of Umudioga site and that of the South prevailing wind on the flare was strong; while from the West it was mild causing a noticeable effect on the LST to be felt in the North-West direction.

\section{Summary and Conclusions}

The satellite data made available for the research work spanned a length of 27 years and that of meteorological data is 21 years, making an appreciably conclusive results to be safely drawn. Wind directions and wind speeds for data acquisitions dates were applied to the South prevailing for the 11 sites. The results show that for Eleme I and II, and Onne the p-values results showed that no statistically significant relationships between $\delta$ LST values in different directions existed. For Obigbo site, the wind direction (South) for data acquisition date combined with the South prevailing wind to generate a noticeable impact on the LST towards the North-East and the North-West directions. For Alua, Bonny, Chokocho, Rukpokwu, Umurolu and Sara sites, the pvalue obtained is statistically significant for all the 3 $\left(\delta \mathrm{LST}_{\mathrm{NE}}, \delta \mathrm{LST}_{\mathrm{NS}}\right.$ and $\delta \mathrm{LST}_{\mathrm{NW}}$ ) relationships; therefore, producing a circle flare $\delta$ LST footprint. For Umudioga site, only $\delta \mathrm{LST}_{\mathrm{N}}$ versus $\delta \mathrm{LST}_{\mathrm{W}}$ is statistically significant, causing a noticeable effect on the flare $\delta$ LST in the North-West direction. The research showed that wind directions and wind speeds contribute to the spatiotemporal variation of the LST at the flaring sites in the Niger Delta. Based on these results, it can be concluded 
that the volume and rate of burning gas, and the speed of the South wind at the time of satellite overpass are major factors that determine the influence of the South prevailing wind on the LST retrieved at the flaring sites in the Niger Delta.

As seen, there are limitations encountered in this study for example, the available Landsat data covers only dry season in Nigeria, hence a further research is required to investigate and compare for the wet season data too. In addition, the meteorological data gathered was collated on a monthly basis, thereby making diurnal wind pattern difficult; this calls for further studies because the nonanalysis of the diurnal wind patterns could lead to underestimation of the impacts of the wind on the LST retrieved at the study sites. The following recommendations are made: Curbing gas flaring in Nigeria is a veritable factor for enforcing standard of living and sustainable development. The problem of gathering gas to a central location can be solved by building mini and micro gas power plants in remote areas where the gas flaring occurs. Also, adequate geographical coverage of natural gas pipeline distribution network as it is done for oil products can help curb flaring. Strict adherence to the suggested applications of flared gas would serve as the way forward for Nigeria in conservation of gas and her ecosystem. Contradictorily, companies undertaking oil activities in Nigeria are the same ones handling similar activities in Europe and America, where flaring have been reduced to a minimal level. Therefore, the technologies to re-inject and add value to the associated gas are known all over the world; Nigeria's case should not be treated otherwise.

\section{Acknowledgements}

Landsat data and MODTRAN ATMCORR Calculator were produced by USGS; meteorological data was produce by NMA; and many thanks to Jill Schwarz for MATLAB coding and guidance.

\section{References}

Ajao, E. A., Anurigwo, S. (2002). Land-Based Sources of Pollution in the Niger Delta, Nigeria. Ambio (13):442-445.

Akinola, A. O. (2018). Resource Misgovernance and the Contradictions of Gas Flaring in Nigeria: A Theoretical Conversation. Journal of Asian and African Studies (53): 749-763, doi.org/10.1177/0021909617722374,

Alvarez, J. (2009). Land Cover Verification Along Freeway Corridors, Natomas Basin Area, California, USA.

Anejionu, O. C. D., Blackburn, G. A., Whyatt, J. D. (2014). Satellite Survey of Gas Flares: Development and Application of a Landsat Based Technique in the Niger Delta. International Journal of Remote Sensing, (35): 1900-1925.

Anejionu, O. C. D., Blackburn, G. A., Whyatt, J. D. (2015). Detecting Gas Flares and Estimating Flaring
Volumes at Individual Flow Stations Using MODIS Data. Remote Sensing of Environment (158): 81-94.

Antai, R. E., Osuji, L. C., Obafemi, A. A., Onojake, M. C., Antai, H. R. (2020). Seasonal Investigation of Meteorological Variables Effects on Air Pollution in Eleme, Rivers State, Nigeria. IOSR Journal of Environmental Science, Toxicology and Food Technology (IOSR-JESTFT) 14(4): 23-30.

Aromolaran, O. (2012). Determination of Greenhouse Gas Emission Resulting from Gas Flaring Activities in Nigeria. Energy Policy (45): 666-670, doi:10.1016/j.enpol.2012.03.018.

Barber, D. (2021). The Four Forces That Influence Wind Speed and Wind Direction. Sciencing.com

Barsi, J. A., Schott, J. R., Palluconi, F. D., Hook, S. J. (2005). Validation of a Web-Based Atmospheric Correction Tool for Single Thermal Band Instruments. Earth Observing Systems $X$, Proceedings of SPIE Bellingham, WA, 2005

Casadio, S., Arino, O., Minchella, A. (2012). Use of ATSR and SAR Measurements for the Monitoring and Characterisation of Night-time Gas Flaring from Off-shore Platforms: The North Sea Test Case. Remote Sensing of Environment (123): 175-186.

Caseiro, A., Gehrke, B., Rücker, G., Leimbach, D., Kaiser, J. W. (2019). Gas Flaring and Black Carbon Emissions in 2017 Derived from Sentinel-3A SLSTR. Earth System Science Data 1-35, doi.org/10.5194/essd-2019-99

Caseiro, A., Rücker, G., Tiemann, J., Leimbach, D., Lorenz, E., Frauenberger, O., Kaiser, J.W. (2018). Persistent Hot Spot Detection and Characterisation Using SLSTR. Remote sensing 10(1118):1-28; doi:10.3390/rs10071118

Chander, G., Markham, K. (2003). Revised Landsat-5 TM Radiometric Calibration Procedures and Postcalibration Dynamic Ranges. IEEE Transactions on Geosciences and Remote Sensing 41(11): 2674-2677.

Chen, F., Zhao, X., Ye, H. (2012). Making Use of Landsat 7 SLC-off ETM+ Image through Different Recovering Approaches. Postgraduate Conference on Infrastructure and Environment (3rd IPCIE) 2: 557-563.

Coll, C., Galve, J. M., Sanchez, J. M., Caselles, V. (2010). Validation of Landsat 7 ETM+ Thermalband Calibration and Atmospheric Correction with Ground-based Measurement. IEEE Transaction on Geosciences and Remote Sensing 48(1): 547-555.

Dung, E. J., Bombom, L. S., Agusomu, T. D. (2008). The Effects of Gas Flaring on Crops in the Niger Delta, Nigeria. GeoJournal (73): 297-305.

Edokpa, D. O., Nwagbara, M. O. (2017). Atmospheric Stability Pattern over Port Harcourt, Nigeria. Atmospheric Pollution 5(1): 9-17. doi: 10.12691/jap5-1-2).

Elvidge, C. D., Zhizhin, M., Baugh, K., Hsu, F. C., Ghosh, T. (2015). Methods for Global Survey of Natural Gas Flaring from Visible Infrared Imaging Radiometer Suite Data. Energies (9): 14.

Elvidge, C. D., Zhizhin, M., Hsu, F. C., Baugh, K. E. (2013). VIIRS Nightfire: Satellite Pyrometry at Night. Remote Sensing (5): 4423-4449. 
Eze, J. I., Obiegbu, M. E., Jude-Eze, E, N. (2005). Statistics and Quantitative Methods for Construction and Business Managers. The Nigerian Institute of Building, Yum-Seg (Nig.) Enterprises, 4, George Street, Apata, Somolu, Lagos, Nigeria.

Fagbenle, R. L., Karayiannis, T. G. (1994). On the Wind Energy Resource of Nigeria. International Journal of Energy Research 18: 493-508.

Faruolo, M., Coviello, I., Filizzola, C., Lacava, T., Pergola, N., Tramutoli, V. (2014). A satellite-based Analysis of the Val d'Agri Oil Center (Southern Italy) Gas Flaring Emissions. Natural Hazards Earth System Science (14): 2783-2793.

Faruolo, M., Lacava, T., Pergola, N., Tramutoli, V. (2018). On the Potential of the RST-FLARE Algorithm for Gas Flaring Characterization from Space. Sensors 18: 2466.

Google Earth. (2021). Location of flaring sites in Rivers State, Niger Delta, Nigeria. Ismail, O., Umukoro, G. (2012). Global Impact of Gas Flaring. Energy Power Engineering (4): 290302, doi:10.4236/epe.2012.44039.

Julius, O. O. (2011). Environmental Impact of Gas Flaring within Umutu-Ebedei Gas Plant in Delta State, Nigeria. Arch. Applied Science Research (3): 272-279.

Kaufman, Y. J., Karnieli, A, Tanre, D. (2000). Detection of Dust Over Deserts Using Satellite Data in the Solar Wavelengths. IEEE Transactions on Geosciences and Remote Sensing 38: 525-531.

Liu, Y., Hu, C., Zhan, W., Sun, C., Murch, B., Ma, L. (2018). Identifying Industrial Heat Sources Using Time-series of the VIIRS Nightfire product with an Object-oriented Approach. Remote Sensing of Environment (204): 347-365.

Lu, W., Liu, Y., Wang, J., Xu, W., Wu, W., Liu, Y., Zhao, B., Li, H., Li, P. (2020). Global Proliferation of Offshore Gas Flaring Areas. Maps 16(2): 396-404.

Maaharjan, A. (2018). Land Use/Land Cover of Kathmandu Valley by Using Remote Sensing and GIS. M.Sc. Dissertation, Department of Environmental Science, Institute of Science and Technology, Tribhuvan University, Kirtipur, Kathmandu, Nepal.

Micheal, E. (2019): Despite Paucity of Funds, Nigeria Flares N461 bn Gas in 2019. Vanguard News.

Morakinyo, B. O. (2015). Flaring and Pollution Detection in the Niger Delta using Remote Sensing. Ph.D Thesis, School of Marine Science and Engineering, University of Plymouth, Plymouth, United Kingdom.

Morakinyo, B. O., Lavender, S. and Abbott, V. (2020a). Assessment of Uncertainties in the Computation of Atmospheric Correction Parameters for Landsat 5 TM and Landsat 7 ETM+ Thermal Band from Atmospheric Correction Parameter (ATMCORR) Calculator. British Journal of Environmental Sciences 8(1): 20-30.

Morakinyo, B. O., Lavender, S. and Abbott, V. (2020b). Retrieval of Land Surface Temperature from Earth Observation Satellites for Gas Flaring Sites in the Niger Delta, Nigeria. International Journal of
Environmental Monitoring and Analysis 8 (3): 59-74. doi: 10.11648/j.ijema.20200803.13

Morakinyo, B. O., Lavender, S., Schwarz, J. and Abbott, V. (2019). Mapping of Land Cover and Estimation of their Emissivity Values for Gas Flaring Sites in the Niger Delta. British Journal of Environmental Sciences 7(2): 31-58.

NASA. (2002). National Aeronautics and Space Administration. Landsat 7 ETM+ Science Data

Nigerian Infopedia (2021). Map of the Niger Delta.

Nwabughiogu, L. (2021). Nigeria Committed to Achieving Complete Eliminating Gas Flaring by 2025.

Nwaogu, L. A., Onyeze, G. O. C. (2020). Environmental Impacts of Gas Flaring on Ebocha-Egbema, Niger Delta, Nigeria. Energy and Environmental Research 8(1): 1-11.

Nwoye, C. I., Nwakpa, S. O., Nwosu, I. E., Odo, J. U., Chinwuko, E. C., Idenyi, N. E. (2014). MultiFactorial Analysis of Atmospheric Noise Pollution Level Based on Emitted Carbon and Heat Radiation during Gas Flaring. Atmospheric Pollution (2): 2229, doi:10.12691/jap-2-1-5.

Oyewole, J. A., Aro, T. O. (2018). Wind Speed Pattern in Nigeria (A Case Study of Some Coastal and Inland Areas). Applied Science and Environmental Management 22 (1): 119-123.

Qin, Q., Zhang, N., Nan, P., Chai, L. (2011). Geothermal Area Detection Using Landsat ETM+ Thermal Infrared Data and Its Mechanistic Analysis: A Case Study in Tengchong, China. International Journal of Applied Earth Observation and GeoInformation 13: 552-559.

Reed, R. J. (1986). Combustion Handbook. North American Manufacturing Company, Cleveland, Oklahoma, USA, Volume 1.

Şatır, O., Berberoğlu, S. (2012). Land Use/Cover Classification Techniques Using Optical Remotely Sensed Data in Landscape Planning, Landscape Planning,

Sekyi, A. K. (2017). The Impact of Gas Flaring on Man and His Environment and the Way Out. Engineering and Management Sciences 2(3): 82-90.

Tokuşlu, A., Bayırhan, İ., Gazioğlu, C. (2020). Investigation the effect of sox emission reduction on transit ships emissions as of January 1, 2020, Thermal Science 24(1):149-155, doi.10.2298 /TSCI20S1149T

Ülker, D., Bayırhan, İ., Mersin, K., Gazioğlu, C. (2020). A comparative $\mathrm{CO} 2$ emissions analysis and mitigation strategies of short-sea shipping and road transport in the Marmara Region, Carbon Management, 11(6): doi.10.1080/ 17583004. 2020.1852853.

Zhang, X., Scheving, B., Shoghli, B., Zygarlicke, C., Wocken, C. (2015). Quantifying Gas Flaring $\mathrm{CH}_{4}$ Consumption Using VIIRS. Remote Sensing (7): 9529-9541. 